\title{
Model Arsitektur Percabangan Beberapa Pohon di Taman Nasional Alas Purwo
}

\author{
${ }^{1)}$ Gustini Ekowati, ${ }^{2)}$ Serafinah Indriyani dan ${ }^{3)}$ Rodiyati Azrianingsih \\ ${ }^{1,2,3)}$ Jurusan Biologi, Fakultas Matematika dan Ilmu Pengetahuan Alam, Universitas Brawijaya \\ Alamat korespondensi : ${ }^{1)}$ gekowati@yahoo.com ${ }^{2)}$ indriyani.serafinah04@gmail.com \& ${ }^{3)}$ rodiyati@ub.ac.id
}

\begin{abstract}
ABSTRAK
Taman Nasional Alas Purwo (TNAP) telah ditunjuk sebagai sebuah cagar biosfer dunia oleh UNESCO. Cagar biosfer adalah daerah yang terdiri dari ekosistem asli, ekosistem unik, atau ekosistem yang telah terdegradasi seluruh elemen alaminya; oleh karena itu, biosfer ini dilindungi dan dilestarikan untuk penelitian dan pendidikan. Untuk mendukung upaya perlindungan dan pelestarian, penelitian dasar untuk memberdayakan spesies tanaman perlu dilakukan. Penelitian ini bertujuan untuk mengkarakterisasi model arsitektur berdasarkan percabangan pohon dan membuat kunci determinasi atau identifikasi spesies tumbuhan dalam TNAP tersebut. Eksplorasi daerah TNAP dilakukan dengan menggunakan metode survei; hal tersebut dilakukan dengan melewati triangulasi jembatan Sunglon Ombo sampai Pancur, berputar ke gua Istana, pondok Sadengan dan kembali ke Triangulasi. Model arsitektur dan jenis percabangan pohon di TNAP juga diamati. Mereka dikelompokkan berdasarkan 23 model arsitektur yang sudah diketahui. Data dianalisis secara deskriptif kemudian dibuat kunci determinasi. Hasil penelitian menunjukkan 11 model arsitektur pohon yang terdiri dari Troll 14 jenis, Scarrone 4 jenis, Corner 4 jenis, Leeuwenberg 3 jenis, Aubreville 3 jenis, Mc Clure 3 jenis, Pedanda 5 jenis, Masart 2 jenis, Holtum 1 jenis, Prevost 1 jenis, dan Koriba 1 jenis. Selain itu, 11 tanaman sebagai contoh model arsitektur dideskripsikan, dilengkapi dengan foto, dan catatan spesies endemik TNAP. Kunci identifikasi untuk beberapa pohon bercabang juga ditambahkan tergantung pada model.
\end{abstract}

Kata kunci: Taman Nasional Alas Purwo, model percabangan, model arsitektur pohon, kunci identifikasi

\section{ABSTRACT}

The Alas Purwo National Park (APNP) has been designated as a world reserved biosphere by UNESCO. Reserved biosphere is an area consisting of the original ecosystem, unique ecosystems, or ecosystems that have degraded their entire natural elements; therefore, this biosphere is protected and preserved for research and education. To support the protection and preservation efforts, it is important to conduct a basic research for empowering the plant species. This study aimed to characterize the architectural model based on the branching tree and to make a key determination or identification of tree species in the APNP. Exploration of APNP area was conducted using the survey methods; it had been done by passing through the triangulated, going to the bridge Sunglon Ombo until Pancur, then rotating to the cave Istana, the lodge of Sadengan, then going back to the triangulated. The architectural model and the type of branch of trees in APNP were observed. They were stratified by 23 of the known architectural models. The data was descriptively analyzed then the key determination was made. The result showed 11 of tree architecture models consisted of Troll 14 types, Scarrone 4 types, Corner 4 types, Leeuwenberg 3 types, Aubreville 3 types, Mc Clure 3 types, Rauh 5 types, Masart 2 types, Holtum 1 type, Prevost 1 type, and Koriba 1 type. Furthermore, the 11 plants as the examples of the architectural model were described, completed with photos, and notes on endemic species of APNP. The identification key for multiple branching trees also was added depending on the model.

Keywords: Alas Purwo National Park, branch model, tree architectural model, identification keys

\section{PENDAHULUAN}

Taman Nasional Alas Purwo di Kabupaten Banyuwangi ditetapkan sebagai Taman Nasional sejak tahun 1992. Selanjutnya, taman nasional ini ditetapkan sebagai jaringan cagar biosfer dunia oleh
Organisasi Pendidikan, Keilmuan dan Budaya Perserikatan bangsa-Bangsa (PBB) atau UNESCO. Penetapan sebagai cagar biosfer dunia dilakukan pada sidang "International Coordinating Council" (ICC) Program MAB (Man and The Biosphere) UNESCO ke 28 di Kota Lima, 18-20 Maret 2016. Cagar Biosfer 
adalah suatu kawasan yang terdiri dari ekosistem asli, ekosistem unik, dan atau ekosistem yang telah mengalami degradasi yang keseluruhan unsur alamnya dilindungi dan dilestarikan bagi kepentingan penelitian dan pendidikan [1].

Penelitian tentang model arsitektur pohon telah dilakukan pada beberapa lokasi di Jawa Timur yaitu di Kebun Raya Purwodadi, Ruang Terbuka Hijau di Kota Malang. Meskipun demikian, penelitian tentang model arsitektur percabangan yang dilengkapi dengan kunci identifikasi belum banyak dilaporkan.

Penelitian model arsitektur percabangan ini penting dilakukan untuk mendapatkan database keanekaragaman model arsitektur tumbuhan yang tumbuh di TNAP. Dengan demikian hal ini sebagai bentuk kontribusi untuk mengkonservasi tumbuhan di Indonesia.

\section{METODE PENELITIAN}

Penelitian ini akan dilakukan pada bulan Mei sampai Oktober 2016. Survei vegetasi di lapang meliputi pengamatan morfologi, pemotretan model arsitektur percabangan dilakukan di area studi di Taman Nasional Alas Purwo (TNAP), Kabupaten Banyuwangi, Jawa Timur. Pengamatan lebih lanjut struktur tumbuhan, dokumentasinya dan dilakukan di Laboratorium Taksonomi dan Struktur Tumbuhan, Jurusan Biologi, FMIPA, Universitas Brawijaya.

\section{Deskripsi Area Studi}

Area studi penelitian ini adalah Taman Nasional Alas Purwo (TNAP), Kabupaten Banyuwangi, Propinsi Jawa Timur. Area ini terletak di ujung tenggara Pulau Jawa dengan luas wilayah $\pm 540 \mathrm{~km}^{2}$. Secara geografis wilayah ini terletak pada $114^{\circ} 20^{\prime}-114^{\circ} 36^{\prime}$ BT dan $8^{\circ} 25^{\prime}-8^{\circ} 47^{\prime}$ LS.

\section{Eksplorasi}

Penelitian ini dilakukan dengan melakukan jelajah (survey) dan pengamatan secara langsung terhadap model arsitektur percabangan batang pada tumbuhan yang terdapat di lokasi penelitian. Penjelajahan wilayah TNAP dilakukan dari ruas jalan lintasan wisata safari. Lintasan ini membentang dari Triangulasi, Jembatan Sunglon Ombo sampai Pancur, kemudian memutar ke Gua Istana, Pondok Sadengan dan kembali ke Triangulasi. Sampel diambil dari area yang memungkinkan dijangkau.

\section{Pengamatan Model Arsitektur \\ Percabangan Pohon}

Pengamatan model arsitektur percabangan pohon dilakukan dengan pengamatan langsung dan pemotretan tumbuhan yang diamati, sebagai dokumentasi penelitian. Model arsitektur percabangan pohon dikelompokkan berdasarkan 23 model arsitektur percabangan pohon [2].

\section{Identifikasi Tumbuhan}

Identifikasi dilakukan secara langsung di area studi dan secara tidak langsung di laboratorium. Identifikasi pohon dilakukan dengan mengamati morfologi pohon meliputi bentuk kanopi, batang, daun dan bunga. Hasil pengamatan diklasifikasikan dengan mengacu pada Flora of Java [3], Identification of tropical Woody Plants in The Absence of Flower. A Field Guide [4], An Essay on the Architecture and Dynamics of Growth of Tropical Trees [2], An Encyclopedia of cultivated Palms [5], Plant Resources of South East Asia 5. Timber Trees: Major commmercial Timbers [6], Plant Resources of South East Asia 7. Bamboos [7], Flora: Untuk Sekolah di Indonesia [8].

\section{HASIL DAN PEMBAHASAN}

\section{Model Arsitektur Percabangan Pohon dan Deskripsi beberapa Pohon di Taman Nasional Alas Purwo (melalui lintasan safari)}

Berikut model arsitekstur dan deskripsi morfologi pohon yang digunakan sebagai contoh model arsitektur, jenis tersebut (Tabel $1)$ :

1.Corypha utan Lamk. (gebang) merupakan pohon dengan batang tumbuh terbatas, tanpa cabang (kecuali pada kasus tertentu), bunga terminal. Contoh dari model Holttum (Gambar 1). Palem yang kokoh kuat, berbatang satu dengan bentuk tiang, tinggi 10-30 m, setelah pembentukan buah lambat laun mati. Daun berjejal-jejal menjadi tajuk yang lebar; panjang tangkai 2-7 $\mathrm{m}$, dari atas lebar dan beralur dalam, pada tepi da duri tempel yang hitam; helaian daun bulat sampai bulat telur, 
tebal seperti kulit, dengan tulang daun tengah yang kuat, sampai kira-kira separuh bercangap menjari, diameter 2-3,5 m [8].

2.Cocos nucifera L. (kelapa) merupakan pohon yang hanya memiliki satu meristem, monopodial (indeterminate), lateral inflourescence [9]. Monopodial atau indeterminate merupakan percabangan dengan cabang pokok tampak, karena lebih besar, lebih panjang dan lebih cepat pertumbuhannya dari pada cabang-cabangnya [10]. Pohon tidak bercabang dengan tinggi batang sampai lebih dari $30 \mathrm{~m}$ dan diameter $40 \mathrm{~cm}$. Batang lurus berwarna abu-abu sampai kecoklatan, tajuk terurai, tangkai dan rakis berwarna hijau dan ada yang berwarna kuning. Pembungaan terletak pada bagian aksial. Contoh dari model Corner (Gambar 2).

\section{Aleurites moluccana Willd. (kemiri)} merupakan pohon yang memiliki batang monopodial yang tumbuh secara ritmik, percabangan orthotropic dan simpodial. Kanopi berbentuk round. Letak pembungaan lateral [2]. Pohon, tinggi 10-40 m. Daun muda, ranting dan karangan bunga dihiasi dengan rambut bintang yang rapat, sangat pendek, berwarna perak mentega. Daun bertangkai panjang, dengan dua kelenjar pada ujung tangkai; helaian daun bulat telur bentuk lancet, hanya pada pangkal bertulang daun menjari, dengan bintik yang transparan dan tidak sama [10]. Contoh dari model Scarrone (Gambar 3).

4.Vitex pinnata (laban) merupakan pohon yang tersusun oleh batang monopodial dan cabang-cabang plagiotropic kecuali untuk bagian prosimal; batang monopodial merupakan reorientasi tambahan aktivitas kambium menjadi posisi vertikal [2]. Contoh dari model Troll (Gambar 4).

\section{Barringtonia asiatica Kurz. (keben)} merupakan pohon yang memiliki ciri batang simpodium. Kuncup terminal terhenti karena jaringan meristem apeks berdiferensiasi menjadi parenkim. Kuncup aksilar yang berkembang dekat di bawahnya, membentuk koulomner yang semula identik namun terjadi perbedaan. Satu menjadi koulomner batang dan yang lain menjadi koulomner cabang. Contoh tumbuhan Model arsitektur Koriba pada Gambar 5.
6.Gigantocloa manggong (bambu manggong) pohon yang memiliki aksis terdeferensiasi menjadi dua macam, yaitu aksis batang pada bagian basal dan bagian liar, percabangan berdaun yang tersusun plagiotropik. Contoh tumbuhan Model Mc Clure pada Gambar 6 dan Lampiran 2.

7.Calopyllum inophyllum L. (nyamplung) merupakan model arsitektur yang memiliki ciri batang berupa simpodium, namun setiap koulomner menghasilkan lebih dari satu koulomner anak di ujungnya yang menempati ruang yang ada [2]. Pohon dengan daun berhadapan, daun-daun mengkilat, kaku seperti kulit, urat daun halus, sejajar yang agak lurus terhadap tulang daun tengah. Batang seringkali bercabang rendah, kebanyakan dengan bongol-bongol [11]. Contoh tumbuhan dengan Model arsitektur Leeuwenberg pada Gambar 7.

8.Manilkara kauki Dub. (sawo kecik) merupakan pohon dengan batang pokok membentuk percabangan simpodial. Batang bawah monopodial tumbuh ritmik dengan cabang-cabang simpodial plagiotropik yang tersusun dari unit-unit simpodial tak terbatas (indeterminate) [2]. Pohon, tinggi 15-20 m. Daun berkelopak pada ujung ranting, bulat telur terbalik, panjang 5-12 cm, serupa kulit, sisi atas hijau tua, sisi bawah kelabu atau kelabu cokelat [10]. Contoh tumbuhan dengan Model Aubreville pada Gambar 8.

9.Swietenia mahagoni Jack. (mahoni) merupakan pohon model Rauh adalah model arsitektur pohon dengan ciri batang monopodial dengan pola pertumbuhan ritmik serta membentuk pola percabangan orthotropic. Pola percabangan ini berhubungan dengan batang perbungaannya, di mana umumnya lateral. Percabangan pada arsitektur pohon model Rauh berbentuk orthotropic [2]. Pohon yang kurang-lebih menggugurkan daun, dapat mencapai tinggi $35 \mathrm{~m}$. Tajuk rapat, lebat, hijau tua. Batang kurang lebih berakar papan [11]. Jenis pohon dengan model Rauh ada pada Gambar 9.

10.Alstonia scholaris (pulai) merupakan model arsitektur Prevost adalah pohon dengan ciri-ciri batang bercabang, poliaksial, dengan aksis vegetatif tidak ekuivalen, homogen (terdiferensiasi dalam bentuk aksis 
orthotropik), percabangan seluruhnya akrotonik dalam membentuk batang, konstruksi modular dengan cabang flagiotropik yang sedikit, model umumnya mempunyai perbungaan terminal yang berfungsi baik, pertumbuhan tinggi simpodial modular, konstruksi modular, model tidak sama dari pangkal, model batang terbentuk kemudian setelah terjadinya percabangan antara batang dan cabang nampak jelas perbedaannya [2]. Pohon besar dan tinggi. Batang lurus, bulat, kebanyakan tanpa aluralur, tanpa atau berakar papan. Daun tersusun dalam lingkaran terdiri dari 4-8 daun. Helaian daun sebelah atas hijau mengkilat, sebelah bawah hijau muda guram, tidak berbulu. Pada pangkal tangkai daun sisi sebelah dalam didapati selaput yang menutupi kelenjar yang terdapatpada pangkal helai daun [11]. Jenis pohon yang ditemukan di lokasi penelitian dan memiliki model arsitektur seperti ini adalah pada Gambar 10.

11.Syzygium polyanthum (salam) Model Massart yaitu model pohon dengan ciri-ciri batang batang bercabang, poliaksial, dengan aksis vegetatif tidak ekuivalen, homogen (terdiferensiasi dalam bentuk aksis ortotropic), percabangan seluruhnya acrotonic dalam membentuk batang, bukan konstruksi modular dengan perbungaan lateral, pola percabangan umum monopodium, pertumbuhan batang dan cabang ritmik dan percabangan flagiotropik bukan karena aposisi, monopodial atau simpodial karena substitusi. Pohon dengan model Massart adalah Gambar 11.

Hasil penelitian pada di Taman Nasional Alas Purwo (melalui lintasan safari) didapatkan model arsitektur percabangan pohon dari 41 spesies pohon.

Tabel 1. Model Arsitektur Percabangan Pohon di TNAP melalui lintasan safari

\begin{tabular}{|c|c|c|c|c|}
\hline No & Famili & Spesies & $\begin{array}{c}\text { Nama } \\
\text { Daerah/Indonesia }\end{array}$ & $\begin{array}{l}\text { Model arsitektur } \\
\text { pohon }\end{array}$ \\
\hline 1 & Mimosaceae & Albizia procera & Weru & Troll \\
\hline 2 & Annonaceae & Annona muricata L. & Sirsak & Troll \\
\hline 3 & Annonaceae & Annona reticulata $\mathrm{L}$. & Buah nona & Troll \\
\hline 4 & Annonaceae & Annona squamosa $\mathrm{L}$. & Srikaya & Troll \\
\hline 5 & Caesalpiniaceae & Cassia javanica $\mathrm{L}$. & Trengguli & Troll \\
\hline 6 & Lythraceae & Lagerstremia speciosa L. & Bungur laut & Troll \\
\hline 7 & Rubiaceae & Anthocephalus chinensis & Jabon & Troll \\
\hline 8 & Leguminoceae & Pongamia pinnata L. & Bangkongan & Troll \\
\hline 9 & Verbenaceae & Vitex pinnata & Kayu laban & Troll \\
\hline 10 & Mimosaceae & Albizia saman & & Troll \\
\hline 11 & Mimosaceae & Acacia auriculiformis & Akasia & Troll \\
\hline 12 & Verbenaceae & Tectona grandis $\mathrm{L}$. & Jati & Troll \\
\hline 13 & Papilionaceae & Erythrina fusca & Dadap & Troll \\
\hline 14 & Caesalpiniaceae & Tamarindus indica $\mathrm{L}$. & Asam & Troll \\
\hline 15 & Euphorbiaceae & Aleurites molluccana Willd. & Kemiri & Scarrone \\
\hline 16 & Caesalpiniaceae & Casia siamea Lamk. & Johar & Scarrone \\
\hline 17 & Malvaceae & Hibiscus macrophyllus & Waru payung & Scarrone \\
\hline 18 & Malvaceae & Hibiscus tiliaceus L. & Waru laut & Scarrone \\
\hline 19 & Arecaceae & Arenga pinnata Merr. & Aren & Corner \\
\hline 20 & Cycadaceae & Cycas rumphii Mij. & Pakis haji & Corner \\
\hline 21 & Arecaceae & Areca catechu L & Pinang & Corner \\
\hline 22 & Arecaceae & Cocos nucifera $\mathrm{L}$. & Kelapa & Corner \\
\hline 23 & Guttiferae & Calophyllum inophyllum L. & $\begin{array}{l}\text { Nyamplung, } \\
\text { Bintangur }\end{array}$ & Leeuwenberg \\
\hline 24 & Guttiferae & Mamea odorata & Mirip nyamplung & Leeuwenberg \\
\hline 25 & Poaceae & $\begin{array}{l}\text { Tabernaemontana } \\
\text { macrocarpa }\end{array}$ & & Leeuwenberg \\
\hline
\end{tabular}




\begin{tabular}{|l|l|l|l|l|}
\hline 26 & Sterculiaceae & Sterculia foetida & Kepuh & Aubreville \\
\hline 27 & Sapotaceae & Manilkara kauki Dub. & Sawo kecik & Aubreville \\
\hline 28 & Combretaceae & Terminalia catappa L. & Ketapang & Aubreville \\
\hline 29 & Poaceae & Gigantochloa manggong & Bambu manggong & Mc Clure \\
\hline 30 & Poaceae & Bambusa sp. & Bambu & Mc Clure \\
\hline 31 & Poaceae & Bambusa bambos & Bambu ori & Mc Clure \\
\hline 32 & Burseraceae & Canarium hirsutum & Kenari berbulu & Rauh \\
\hline 33 & Euphorbiaceae & Antidesma bunius L & Buni, Wuni & Rauh \\
\hline 34 & Moraceae & Ficus benjamina & Beringin & Rauh \\
\hline 35 & Sterculaceae & $\begin{array}{l}\text { Pterospermum javanicum } \\
\text { Pohon }\end{array}$ & Bayur & Rauh \\
\hline 36 & Meliaceae & Swietenia mahagoni Jack. & Mahoni & Rauh \\
\hline 37 & Myrtaceae & Syzygium littorale Bl. & Jambu alas & Massart \\
\hline 38 & Myrtaceae & Syzygium polyanthum & Salam & Massart \\
\hline 39 & Arecaceae & Corypha utan Lamk. & Gebang & Holttum \\
\hline 40 & Apocynaceae & Alstonia scholaris & Pulai/pule & Prevost \\
\hline 41 & Lecythidaceae & Barringtonia asiatica Kurz. & Keben & Koriba \\
\hline
\end{tabular}

\section{Deskripsi model arsitektur beberapa pohon di Taman Nasional Alas Purwo}

Halle et al. [2] telah mendeskripsikan model-model arsitektur pohon hutan terdiri atas 23 model untuk jenis-jenis pohon dan tumbuhan hutan lainnya dijumpai sebagai model pada pohon-pohon hutan di wilayah tropika. Dijelaskan lebih lanjut bahwa arsitektur pohon merupakan abstraksi dari genetik oleh suatu tumbuhan sejak mengawali pertumbuhannya, arsitektur pohon berbeda pengertian dengan pola pertumbuhan, habitus dan bentuk-bentuk tajuk. Arsitektur adalah bentuk dari produk akhir dari suatu pola perilaku pertumbuhan meristem apical, ukuran atau habitus bukan merupakan faktor pembeda karena pohon dengan herba dapat saja memiliki hasil akhir pola perilaku pertumbuhan yang sama.

Deskripsi tumbuhan model arsitektur sebagai berikut:

\section{Model Holttum}

Model Holttum ciri-cirinya adalah palem yang kokoh kuat, tinggi 10-30 m, axis batang tidak bercabang dan monopodial, pada saat masih muda mempunyai duduk daun (filotaksis) spiralis, influorescensia apical. Masa hidup terbatas oleh tumbuhnya bunga monopodial, berarti batang hanya satu tidak bercabang, setelah berbunga kemudian berbuah lambat laun mati. Contoh tumbuhan model arsitektur Holttum yang terdapat di TNAP di sajikan pada Gambar 1.

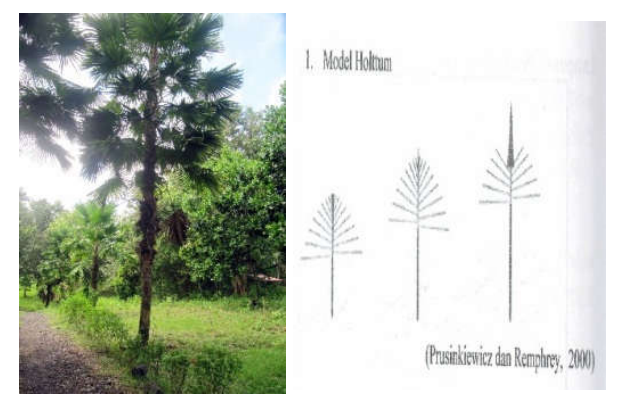

Gambar 1. Corypha utan Lamk. (Gebang)

\section{Model Corner}

Model Corner merupakan model arsitektur pohon yang memiliki ciri batang monopodial dengan perbungaan lateral dan tidak bercabang, karena posisi perbungaannya yang lateral maka meristem apical dapat tumbuh terus. Contoh tumbuhan model arsitektur Corner yang terdapat di Taman Nasional Alas Purwo disajikan pada Gambar 2.

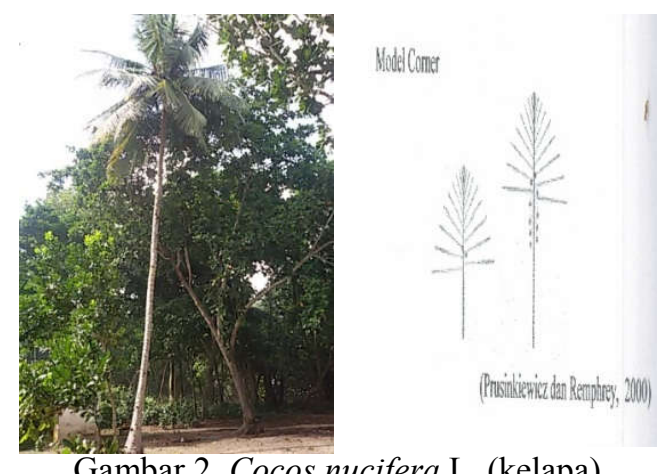

Gambar 2. Cocos nucifera L. (kelapa) 


\section{Model Arsitektur Scarrone}

Model arsitektur pohon Scarrone merupakan model arsitektur pohon dengan ciri-ciri batang bercabang, poliaksial atau pohon dengan beberapa aksis yang berbeda, dengan aksis vegetatif yang tidak ekuivalen dengan bentuk homogen, semuanya orthotropik, percabangan monopodial dengan perbungaan terminal, terletak pada bagian peri-peri tajuk, cabang simpodial nampak seperti konstruksi modular, batang dengan pertumbuhan tinggi ritmik.

Beberapa jenis pohon yang termasuk ke dalam model ini diantaranya Mangga (Mangifera indica), Pandan (Pandanus pulcher), Jambu mete (Anacardium occidentale), Kedondong (Spondias pinnata), Johar (Cassia siamea), Langar (Peltophorum pterocarpum), Waru (Hibiscus tiliaceus) dan masih banyak lagi.

Manfaat lain dengan model arsitektur Scarrone yang dimiliki kemiri yaitu tajuknya yang rapat dan lebar mampu berperan sebagai penahan angin, pembatas, penaung, peneduh, stabilisator tanah dan pengisi lahan-lahan yang kosong, serta nilai keindahan pohon kemiri dengan daunnya yang lebar dan bunga putih kecilnya [12]. Contoh tanaman model arsitektur Scarrone disajikan pada Gambar 3.

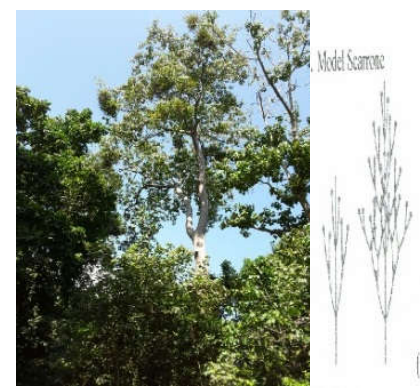

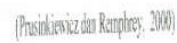

Gambar 3. Aleurites moluccana Willd. (kemiri)

\section{Model Troll}

Model Troll merupakan model arsitektur pohon dengan ciri batang simpodial. Semua sumbu berarah plagiotrop sejak dini. Pohon berbunga setelah dewasa, daun cenderung berhadapan. Sumbu pertama bersifat ortrotop, sumbu berikutnya mulai berdiferensiasi ke arah horisontal secara bertahap dan pohon berbunga setelah dewasa. Pembentukan batang yang tegak terjadi setelah daun gugur. Contoh tumbuhan model arsitektur Troll yang terdapat di Taman Nasional Alas Purwo disajikan pada Gambar 4.
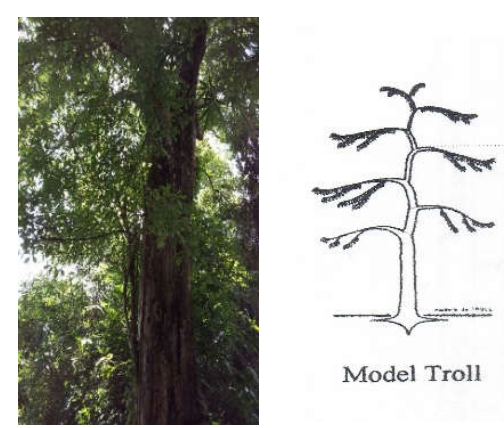

Model Troll

Gambar 4. Vitex pinnata (laban)

\section{Model Koriba}

Model Koriba merupakan model arsitektur pohon yang memiliki ciri batang simpodium. Kuncup terminal terhenti karena jaringan meristem apeks berdiferensiasi menjadi parenkim. Kuncup aksilar yang berkembang dekat di bawahnya, membentuk koulomner yang semula identik namun terjadi perbedaan. Satu menjadi koulomner batang dan yang lain menjadi koulomner cabang. Contoh tumbuhan model arsitektur Koriba yang terdapat di TNAP disajikan pada Gambar 5.

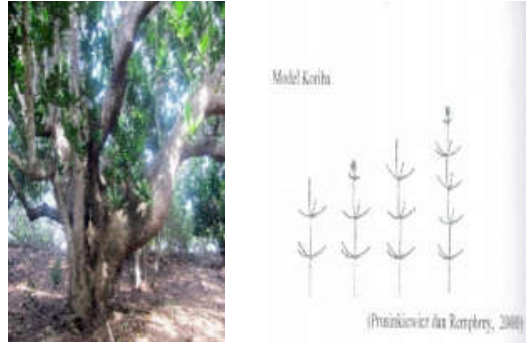

Gambar 5. Barringtonia asiatica Kurz.(keben)

\section{Model Mc Clure}

Model Mc Clure merupakan model percabangan pohon yang memiliki aksis terdiferensiasi menjadi dua macam, yaitu aksis batang pada bagian basal dan bagian luar, percabangan berdaun yang tersusun plagiotropic. Contoh tumbuhan model arsitektur Mc Clure disajikan pada Gambar 6.
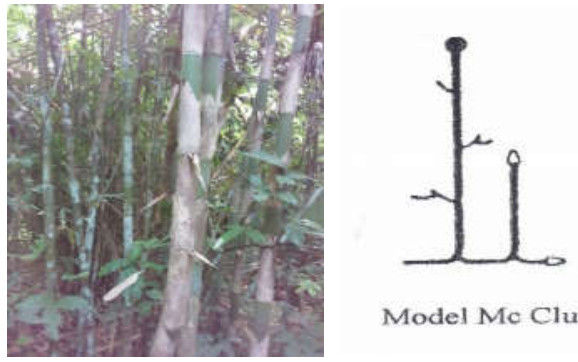

Model Mo Clure

(Oldeman, 1986 \& Bell, 1991)

Gambar 6. Gigantocloa manggong 


\section{Model Leeuwenberg}

Model Leeuwenbwerg merupakan model percabangan pohon yang tersusun dari percabangan simpodial dimana masing-masing unit simpodial mendukung lebih dari satu unit yang sama pada ujung distal [9]. Contoh tumbuhan dengan model arsitektur Leeuwenberg yang terdapat di Taman Nasional Alas Purwo disajikan pada Gambar 7.

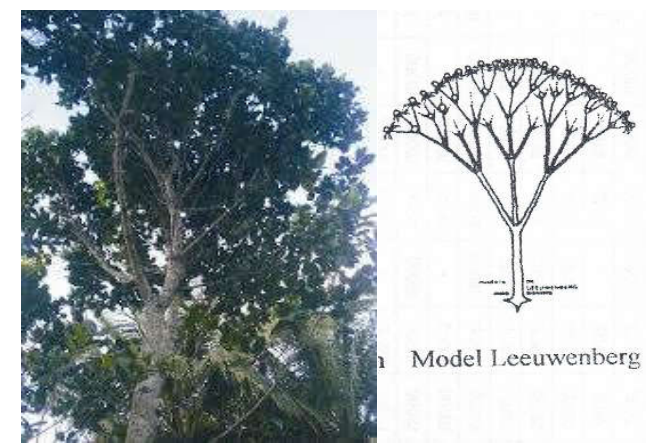

Gambar 7. Calophyllum inophylum L. (nyamplung)

\section{Model Aubreville}

Model Aubreville merupakan model percabangan dengan batang monopodial dengan pertumbuhan ritmik. Bentuk kanopi piramida. Percabangan tumbuh secara ritmik, masing-masing cabang tumbuh plagiotopic dan letak perbungaan lateral.

Contoh pohon yang termasuk model Aubreville adalah pada Gambar 7.

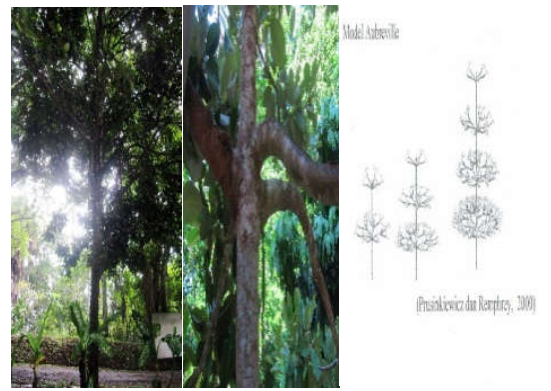

Gambar 8. Manilkara kauki Dub.(Sawo kecik)

\section{Model Rauh}

Model Rauh merupakan model percabangan yang tersusun dari batang monopodial yang tumbuh ritmik, cabang monopodial dan orthotropic. Kanopi berbentuk vase, yang merupakan bentuk kanopi dengan bagian bawah kanopi sempit dan semakin keatas semakin melebar. Letak pembungaan lateral. Model rauh merupakan model arsitektur pohon yang memiliki cirri batang monopodium ortrotp. Pertumbuhan ritmis mengakibatkan cabang tersusun dalam karangan, cabang juga bersifat ortotrop sumbu dapat tumbuh tidak terbatas. Contoh tumbuhan model Rauh adalah pada Gambar 9.
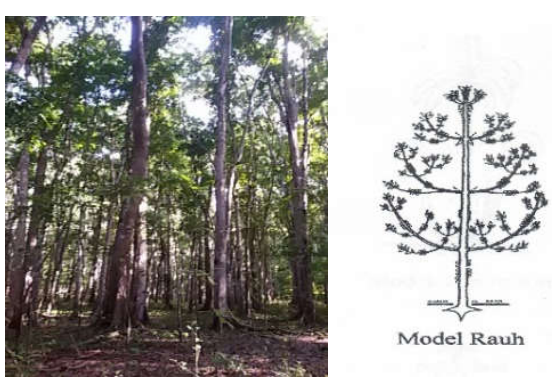

(Oldeman, 1986 \& Bell, 1991)

Gambar 9. Sweitenia mahagoni Jack. (Mahoni)

\section{Model Prevost}

Model Prevost merupakan model arsitektur pohon dengan ciri-ciri batang bercabang, poliaksial, dengan aksis vegetatif tidak ekuivalen, homogen (terdiferensiasi dalam bentuk aksis orthotropik), percabangan seluruhnya akrotonik dalam membentuk batang, konstruksi modular dengan cabang flagiotropik yang sedikit.
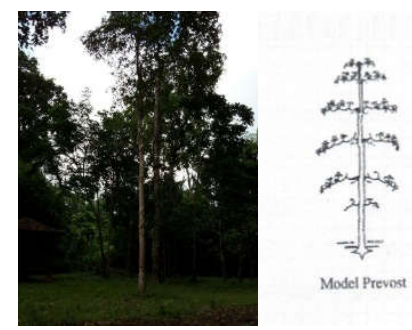

Gambar 10. Alstonia scholaris (pule)

\section{Model Massart}

Model Massart yaitu model pohon dengan ciri-ciri batang batang bercabang, poliaksial, dengan aksis vegetatif tidak ekuivalen, homogen (terdiferensiasi dalam bentuk aksis ortotropic), percabangan seluruhnya acrotonic dalam membentuk batang, bukan konstruksi modular dengan perbungaan lateral, pola percabangan umum monopodium, pertumbuhan batang dan cabang ritmik dan percabangan flagiotropik bukan karena aposisi, monopodial atau simpodial karena substitusi. Pohon dengan model Massart adalah Gambar 11. 


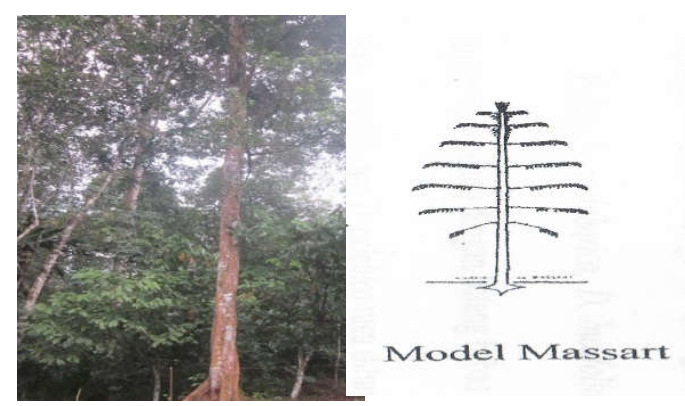

Gambar 11. Syzygium polyanthum (salam)

\section{Kunci identifikasi model arsitektur percabangan pohon}

1. a. Pohon monoaksial ......................... 2

b. Pohon poliaksial .......................... 3

2. a. Pohon monoaksial, memiliki terminal inflourescence .......... model Holttum (Gambar 1)

b. Pohon monoaksial, memiliki lateral inflourescence ..............model Corner (Gambar 2)

3. a. Pohon poliaksial dengan aksis vegetatif yang ekuivalen, perbungaan terminal (Gambar 7) model Leewenberg

Pohon poliaksial dengan aksis vegetatif yang non ekuivalen

4. a. Pohon bercabang dengan aksis vegetatif non ekivalen, kadang-kadang seperti tidak bercabang ............. model Mc Clure (Gambar 6)

b. Pohon bercabang dengan aksis vegetatif non ekivalen, cabang plagiotropnya sedikit ....

5. a. Pohon bercabang dengan aksis vegetatif non ekuivalen, pola percabangan berupa simpodial, tetapi antara pokok dan cabang nampak sangat jelas berbeda . model Prevost (Gambar 10)

b. Pohon bercabang dengan aksis vegetatif ekuivalen, campuran non ekuivalen dan ekuivalen 6

6.a. Pohon bercabang dengan aksis campuran antara ekuivalen dan non ekuivalen, pembentukan batang yang tegak terjadi setelah daun gugur............... model Troll (Gambar 4)

b. Pohon bercabang dengan aksis non ekuivalen, percabangan monopodial, perbungaan 7 latera.....

7. a. Pohon bercabang dengan aksis non ekuivalen, percabangan monopodial, perbungaan lateral, mempunyai batang pokok yang mengalami pertumbuhan ritmik ............ model Rauh (Gambar 9)

b. Pohon bercabang dengan aksis non ekuivalen, percabangan monopodial, perbungaan terminal ....................model Scarrone (Gambar 3)

8. a. Pohon bercabang dengan aksis vegetatif non ekivalen, cabang plagiotropnya sedikit,...................model Koriba (Gambar 5)

b. Pohon bercabang dengan aksis vegetatif non ekivalen, cabang plogiotrop tersusun dalam cabang terpisah 9

9. a. Pohon bercabang dengan aksis vegetatif non ekuivalen, cabang plogiotrop tersusun dalam cabang terpisah dari unitunit simpodial tak terbatas model Aubreville (Gambar 8)

b. Pohon bercabang dengan aksis non ekuivalen, cabang ritmik dan percabangan .............. model Massart (Gambar 11)

\section{KESIMPULAN}

Berdasarkan hasil penelitian dan pembahasan maka didapatkan model arsitektur pohon di Taman Nasional Alas Purwo (melalui lintasan safari) cukup beragam. Diantara 41 jenis yang terpilih sebagai sampel, ditemukan 11 model arsitektur pohon yaitu: Troll (14 jenis), Scarrone (4 jenis), Corner ( 4 jenis), Leeuwenberg (3 jenis), Aubreville (3 jenis), Mc Clure (3 jenis), Rauh (4 jenis), Masart (2 jenis), Holtum (1 jenis), Prevost (1 jenis), Koriba (1 jenis). Dibuat deskripsi pohon yang dipilih sebagai sampel untuk 11 model arsitektur dan kunci determinasi berdasarkan model arsitektur.

\section{DAFTAR PUSTAKA}

[1] TN Alas Purwo. 2016. Menteri LHK Ingin Kembangkan Taman Nasional Alas Purwo. http://news.detik.com/berita/3173806/m enteri-lhk-ingin-kembangkan-tamannasional alas-purwo.

[2] Halle, F., R.A.A. Oldeman \& Tomlinson. 1978. Tropical Trees and Forests. An Architectural Analysis. Springer-Verlag.Berlin Heidelberg, New York. 441 p. 
[3] Backer, C.A. and Bakhuizen Van Den Brink, R.C., 1968. Flora of Java (Spermatophytes Only) Vol. 3. WoltersNoordhoff NV, Groningen.

[4] Keller, R. 2004. Identification of Tropical Woody Plants in The Absence of Flowers. Afield Guide (Second Edition). Birkhauser verlag. Basel.

[5] Riffle, R.I. an P. Craft. 2001. An Encyclopedia of Cultivate Palms. Timber Press.Oregon.

[6] Prosea Indonesia. 1994. Plant resources of south east Asia 5. Timber trees: major commmercial timbers. Yayasan prosea .Bogor.

[7] Prosea Indonesia. 1995. Plant resources of south east Asia 7. Bamboos. Yayasan prosea. Bogor.

[8] Van Steenis, C.G.G.J. 2008. Flora: untuk sekolah di Indonesia. Terjemahan M. Surjowinoto, S. Hardjosuwarno, S.S. Adisewojo, Wibisono, M. Partodidjojo, S. Wirjahardja. Pradnya Paramita. Jakarta.

[9] Bell, A.D.1991. Plant Form. An Illustrated Guide to Flowering Plant Morphology. Oxford University Press. New York.

[10] Tjitrosoepomo, G. 2007. Taksonomi tumbuhan (Spermatophyta). Cetakan kesembilan. Gajah Mada University Press. Yogyakarta.

[11] Samingan, T. 1982. Dendrologi. Jakarta.

[12] Krisnawati, H., Kallio, M. dan Kanninen, M. 2011 Aleurites moluccana (L.) Willd.: Ekologi, Silvikultur dan Produktivitas. CIFOR, Bogor, Indonesia. 